\title{
Analysing the EU's collective securitisation moves towards China
}

\section{Xuechen Chen $^{1} \mathbb{D} \cdot$ Xinchuchu Gao $^{2}$}

Received: 16 January 2021 / Revised: 28 July 2021 / Accepted: 9 September 2021/

Published online: 7 October 2021

(c) The Author(s), under exclusive licence to Springer-Verlag GmbH Germany, part of Springer Nature 2021

\begin{abstract}
This research responds to an increasing volume of scholarly literature unpacking the recent dynamics of EU foreign policy discourses and practices vis-à-vis China. Drawing on the theoretical approach of collective securitisation, this article shows that EU foreign policy towards China since the mid-2010s has witnessed increasing collective securitisation moves directed at multiple policy frames, including Asian regional security frame, economic security frame, political security frame and information and technology and cybersecurity frame. The EU's attempts to securitise China as an existential threat across multiple issue areas have been triggered by a combination of long-term trends and specific sets of precipitating events, which contributed to galvanising the EU's collective securitising discourses and subsequent policy initiatives. However, this research finds that the EU's securitising moves and relevant speech acts have not resulted in a coherent audience response among the EU member states. The divergent views held by the EU's internal audience on whether China should be perceived as an existential threat have hampered the implementation of the EU's collective policy outputs.
\end{abstract}

Keywords European Union · China $\cdot$ Security $\cdot$ Collective securitisation

\section{Introduction}

This research responds to an increasing volume of scholarly literature unpacking the recent dynamics as well as the nature of EU foreign policy discourses and practices vis-à-vis China. With the establishment of a formal diplomatic tie in 1975 and

Xuechen Chen

xuechen.chen@nchlondon.ac.uk

Xinchuchu Gao

x.gao5@1se.ac.uk

1 Faculty of Politics and International Relations, New College of the Humanities at Northeastern, London, UK

2 European Institute, London School of Economics, London, UK 
a strategic partnership in 2003, the EU-China relationship has gained in maturity and depth over the past few decades, becoming undoubtedly one of the most significant relations in global politics (Brown and Beatson 2016; Christiansen et al. 2018). Despite the existence of dense institutional links and regular interactions at bilateral and multilateral levels, the EU's relations with China 'have deteriorated in the last couple of years', as acknowledged by the Chair of Parliament's delegation for relations with China in an interview in October 2020 (Banks 2020). The increasingly uncozy relationship between the EU and China is evidenced in the European Commission's 2019 Joint Communication 'EU-China: A strategic outlook', which for the first time labelled China as 'systemic rival' and 'systemic competitor' (European Commission 2019a, b). The existing academic debate has generated a considerable volume of literature analysing the overarching trends of EU-China relations (Fox and Godement 2009; Rees 2009; Geeraerts 2019) as well as the EU-China interactions in specific policy sectors, such as economic diplomacy (Smith 2014), security (Dorussen and Christiansen 2018) and environmental issues (Scott 2009). Given that the EU and China have significantly reinforced their diplomatic ties and cooperation between the 1990s and the 2010s, much of the existing literature on EU-China relations draws from the liberal institutionalist perspective to analyse the patterns of engagement between the two actors (Christiansen 2016; Cottey 2017). Nevertheless, there has been a lack of theoretically informed empirical analyses examining the recent deterioration of EU-China relationship. ${ }^{1}$ It is therefore worth asking: how can the recent deterioration of EU-China relations be explained? Furthermore, to what extent has the EU's drastic shift in foreign policy discourses towards China impacted the Union's policy outputs vis-à-vis Beijing?

With an aim to shed a new light on these questions, this article draws on the theoretical approach of collective securitisation (see, for example Floyd 2019; Hofmann and Staeger 2019; Sperling and Webber 2019) and argues that EU foreign policy towards China since the mid-2010s has witnessed increasing collective securitisation moves directed at multiple policy frames, including (1) Asian regional security frame, (2) economic security frame, (3) political security frame and (4) information and technology, and cybersecurity frame. The EU's attempts to securitise China as an existential threat across multiple issue areas have been triggered by a combination of long-term trends and specific sets of precipitating events, which contributed to galvanising the Union's collective securitising discourses and subsequent policy initiatives. However, this research finds that the EU's securitising moves and relevant speech acts have not resulted in a coherent audience response among the EU member states. In other words, the Union's internal audience (i.e. EU member states) manifests divergent views on whether China should be perceived as an existential threat, which may hamper the implementation of the EU's collective policy outputs.

\footnotetext{
${ }^{1}$ Although numerous policy analysts have provided useful insights to explain the deterioration of EUChina relationship by prioritising economic factors such as trade tensions and China's failure to enhance market openness (see, for example Von der Burchard 2019; Wright 2020), there is a lack of scholarly discussion on this topic.
} 
Beyond this introduction, the remaining of the article will proceed as follows: the second section provides an overview of the analytical framework based on collective securitisation and the methodology. It further illustrates the theoretical and empirical contributions that this study seeks to make. The third section will apply the six-stage model of collective securitisation to the analysis of the EU's changing discourses and policy initiatives towards China since the 2010s. The final section summarises the article and provides a conclusion.

\section{The analytical framework: collective securitisation}

This section provides an analytical framework for this research, drawing on insights from securitisation theoreticians' recent work on collective securitisation. It begins with a brief introduction to securitisation theory as well as to the term collective securitisation, followed by a literature review on the application of securitisation theory in EU-China relations. It then explains how the analytical framework will be applied to the study.

Securitisation theory was originally developed in the 1990s by the Copenhagen School, whose core members included Barry Buzan, Ole Waever and Jaap de Wilde (Buzan et al.1998). According to Buzan and Waever, securitisation can be defined a process in which an actor identifies a threat and by so doing is able to justify and then call for exceptional measures to address the threat (Buzan and Wæver 2003). It is commonly accepted that securitisation theory has a twofold objective. First, it examines how specific issues move from the category of 'normal' politics to the realm of security wherein the political actor can bypass normal discourse and procedure. Second, securitisation theory 'isolated the mechanisms whereby such as move was enacted' (Sperling and Webber 2016: 25). The process of securitisation is triggered by a speech act-namely a securitising move 'through which an intersubjective understanding is constructed within a political community to treat something as an existential threat to a valued referent object, and to enable a fall for urgent and exceptional measures to deal with the threat' (Buzan and Wæver 2003:491).

While the conventional securitisation theory has received tremendous scholarly attention in International Relations (e.g. Balzacq 2010; Buzan and Wæver 2009; Floyd 2010), it suffers from a number of limitations. Specifically, traditional securisation approach has paid limited attention to how international actors undertake securitisation collectively. Meanwhile, the empirical focus of the early securitisation literature tended to neglect non-state actors and international organisations such as NATO and the EU (Caballero-Anthony 2008; Sperling and Webber 2016). Furthermore, the emergence of new transnational security challenges, including climate change, terrorism and health pandemics, has required a collective response from states. Consequently, states have increasingly relied on international and regional organisations to deal with transnational challenges. It is in this context that Sperling and Webber introduced the term collective securitisation (Sperling and Webber 2016, 2019). According to them: 
Collective securitisation requires that the actor in question acts on behalf of other empowered actors who themselves may have individual securitising imperatives. It entails aggregating these multiple securitisations and giving them authoritative articulation, and so is most obviously undertaken by formal international organisations (Sperling and Webber 2019: 236).

Sperling and Webber further identify thin and thick forms of collective securitisation. The former means that within an international organisation, a state (or a small number of states) has its own security concerns, obtains reactions from other member states and subsequently achieves agreement to empower the international organisation to adopt new security practices (Haacke and Williams 2008: 785-6). In this version of collective securitisation, international organisations do not possess any autonomy and only serve as a platform for bargaining among their members. Examples include the African Union and the United Nations Security Council (Enemark 2017; Haacke and Williams 2008). In the thick version of collective securitisation, despite the aforementioned aggregating function, the international organisation may have securitising preferences separate from its members (Sperling and Webber 2019: 237). In other words, the international organisation can be conceived as an autonomous securitising actor. The European Union (Cross 2017; Huysmans 2006), NATO (Schlag 2016) and the World Health Organisation (Hanrieder and KreuderSonnen 2014) can be understood in this light.

The process of collective securitisation has six distinct yet interrelated stages (Sperling and Webber 2016, 2019). The first stage represents the status quo security discourse and concomitant policies. The second stage is constituted a precipitating event (or series of events) sufficient to disrupt the status quo security discourse. The precipitating event also generates a perception by the securitising actor and audience that the external security environment has undergone significant deterioration. The following two stages- the securitising move and audience response-are analytically separated while codependent through the process of recursive interaction. The securitising move typically takes the form of a speech act, which is composed of official discourses adopted by authoritative actors (e.g. European Commission, Council of the EU, European Parliament in this case). Such speech act identifies the presence of an existential threat to a referent object (i.e. the EU itself) and to the norms and principles that sustain it. Audience response is closely intertwined with securitising move in that audience is typically engaged in a highly intersubjective, interactive process that involves dialogue, negotiation and compromise between the securitising actor and audience (Sperling and Webber 2019). Audience may reject the securitising actor's attempt to securitise an issue or sometimes may amend the process, leading to significant variations in security outcomes that depart from the securitising actor's initial intention (ibid). Notably, whereas audience may take various forms, collective securitisation theory emphasised that the most significant audience is likely to be state representatives within the international organisation (i.e. EU member states). Instead of being passive recipient of a securitising move, audience can empower or even initiate the move, resulting recursive interaction and bargaining between the securitising actor and its audience. The 
fifth and sixth stages focus on the formation and execution of policies that deal with the securitised threat and the routinisation of the new security discourse and concomitant policies. Successful collective securitisation takes place when a securitising actor acquires audience acceptance and subsequent adoption of common policies. Finally, the new status quo emerges and becomes routinised through the adoption of new strategic vocabulary, policy agendas and practices (Sperling and Webber 2016, 2019).

Very few studies have used the term collective securitisation to analyse how the EU reacts to security challenges. In 2019, a special issue undertook an analysis of collective securitisation within the EU across different policy domains, such as energy policy, cyberspace and terrorism. Similarly, Hyttinen and Heinikoski used collective securitisation to illustrate how the EU seeks to securitise money laundering with the use of terrorism-focused discourse (Hyttinen and Heinikoski 2019). The concept of collective securitisation is also used to analyse how other international organisations react to transnational threats. For instance, Sperling and Webber (2016) explored NATO's role as an agent of collective securitisation in the process of (de)securitising Russia in the light of the Crimea/Ukraine crises (Sperling and Webber 2016).

But even the above-referenced literature paid little attention to divergent securitising preferences within an international organisation. One exception is Hofmann and Staeger's work on the collective securitisation of EU energy policy (Hofmann and Staeger 2019). Their research analysed how member states utilised the conceptual ambiguity between different security frames to push for the direction of EU energy integration according to their own national securitising preferences. As Waever stated, any sense of European political identity is still interpreted differently across member states (Wæver 2000). In other words, EU member states may understand security threats differently and, consequently, differ in their need for a policy reaction. It is therefore worth exploring member states' differing securitisation preferences within the process of collective securitisation. This paper seeks to fill this gap by exploring EU member states' divergent securitising preferences with regard to China. By employing the methods of content analysis, this study draws on various forms of primary data, including official announcements published by the EU's authoritative institutions, a wide range of policy papers and media coverage concerning EU-China relations. The study also adopts secondary material, including think-tank policy reports and scholarly publications on International Relations.

\section{The EU's collective securitisation moves towards China through multiple policy frames}

In this section, the six-stage model of collective securitisation (Sperling and Webber 2019 ) is adopted to analyse the EU's changing foreign policy discourse and policy initiatives towards China. 


\section{Status quo discourse (before the 2010s)}

While EU-China formal diplomatic ties can be traced back to 1975 , it was not until the 1990s that the bilateral relationship developed and gained in maturity (Men 2008). By taking a close look at the development of EU strategies towards China with reference to the Union's key official documents, this section illustrates the EU's 'status quo discourse' concerning China between the 1970s and the early 2010s. We argue that, during this period, despite some ups and downs in bilateral relations as well as the EU's ambivalent view of the rise of China, the EU did not make a systematic attempt to securitise China. In other words, the EU did not perceive China as an existential threat or a key security challenge to the Union.

In the first two decades of EU-China bilateral relations, economic and political imperatives drove engagement between the two actors. Following Beijing's amelioration of its relations with the USA in 1972, both the EU and China tended to recognise the other's future international potential. From the EU's perspective, China represented a great economic opportunity for Europe following the 1975 'four modernisation' projects and the opening-up reform in 1978 (Möller 2002). In a draft resolution proposed by the Assembly of the Western European Union in 1978, China was explicitly referred to as 'a significant factor in the maintenance of global peace and security'. The resolution also encouraged European states to develop bilateral ties with China within the framework of the European Economic Community 'with a view to increasing trade between Europe and China' (WEU 1978: 76).

The 1989 Tiananmen event marked a setback in EU-China relations. Although the EU condemned Beijing's violation of human rights and democracy, its official discourse did not frame China as an existential threat. As can be seen in the EU's first policy paper on China, the Tiananmen event was considered as an interruption' in bilateral relations rather than a source of security concern (European Commission 1995). This was followed soon by political readjustment due to the fear of losing the Chinese market to Japanese and US competition especially in investment (European Commission 1995: 8; Christiansen et al. 2018). Besides, the EU believed that China's human rights would improve with the continuing of its opening-up policy and integration into the free market (European Commission 1995: 7).

A closer look at the EU's key policy documents on China before the 2010s (e.g. European Commission 1995, 1998, 2001, 2003, 2006) shows that, despite the existence of concerns over issues such as human rights and democracy, the EU had refrained from identifying China as a source of threat or security challenge. Rather, these documents tended to frame China as an important 'partner', 'a locomotive for regional and global growth' (European Commission 2003: 06), 'an increasingly energetic player in world affairs' and a force for good in promoting peace in regional and global affairs. Moreover, it was noted that 'China's emergence is a welcome phenomenon' (European Commission 2006: 12). 


\section{Precipitating events (since the 2010s)}

According to Sperling and Webber (2019:245), the second phase of collective securitisation is concerned with 'a single precipitating event or a set of cascading events of gravity sufficient to disrupt the status quo and prompt a perception by the securitising actor that the qualitative character of the internal or external security environment has worsened'. While drawing upon the collective securitisation model, this research argues that no single precipitating event has resulted in a shift of the EU's discourse towards China. Rather, the EU's securitisation moves have been triggered by several long-term dynamics within a broader context of global volatilities as well as a set of new trends characterising the EU-China relationship in recent years.

The first longer-term dynamic to affect the EU's perception of China was the decline of Europe in the world economy and in global politics. Whereas in the aftermath of the Cold War, there was some optimism that the EU's global role and power would grow with the potential to develop into a dominant superpower, the EU's overall power in world politics is declining. This is mainly due to its relative economic decline, exacerbated by a series of crises (Euro zone crisis, migration crisis, Brexit) (Webber 2016) and a broader shift of economic power towards Asia. The second dynamic is closely related to the USA's changing foreign policy strategy in general and in relation to China in particular. As Christiansen et al. (2018:8) noted, the role of the USA in EU-China relations has long been considered 'the elephant in the room'. As one of the USA's key allies, the EU has tended to side with the USA on issues such as the South China Sea dispute, as evidenced in the EU-US joint declaration in 2012. More recently, the USA has further increased pressure on EU countries to impose stricter limits on importing $5 \mathrm{G}$ network from China (Baker and Chalmers 2020).

Beyond the abovementioned factors, this research also identified three distinct yet interrelated trends which can be regarded as 'precipitating events' that caused a set of 'exogenous shocks', triggering the EU's collective securitisation of China. First, Chinese foreign policy has undergone a significant change since 2013 under the presidency of Xi Jinping which constituted a crucial precipitating event. As noted by numerous studies, Chinese foreign policy in the past 7 years has been characterised by 'new and self-assured multidimensional activism' in regional and global affairs, as evidenced by a number of major diplomatic initiatives (e.g. Asian Infrastructure Investment Bank, Belt and Road Initiative), and the development of a more holistic approach to the management of diplomatic affairs supported by domestic institutional changes (Zhang 2016:769). These changes represent a departure from China's prior foreign policy principle of 'hiding one's capacity and keeping a low profile', moving towards 'striving for achievement' (ibid). China's significant shift in foreign policy behaviour since the ascendance of $\mathrm{Xi}$ was highlighted as a key driver for the Union to reconsider its strategy towards China (European Commission 2016). The EU emphasised that 'not only is China different internally than it was before the current leadership took over in 2013, but China's increased weight and a renewed emphasis on "going global" mean that it is seeking a bigger role and exerting greater influence on an evolving system of global governance' (European Commission 2016:2). As will be discussed in a later section, China's increasingly 
assertive foreign policy approaches, such as the Belt and Road Initiative (BRI) and reaction to the South China Sea dispute, has triggered and reinforced the EU's discourse of an increasing security threat from China.

Second, there has been a sharp increase in terms of economic and trade friction between the EU and China over the years, along with the investment paradigm shift ${ }^{2}$ and the Union's frustration about China's unfulfilled promises of market reforms (Banks 2020). Whereas there have long been trade and market access issues in EU-China relations, during the 1990s and the 2000s, the EU held the relatively optimistic view that European trade and investment would ultimately transform China into a more open and democratic state with a well-functioning market economy (see European Commission 1995, 1998, 2006). Nevertheless, over the past few years, the EU's concerns over the issues of market access, reciprocity and level playing field have increased drastically. As noted in the EU's 2019 policy paper, China has become a 'strategic competitor for the EU' in trade and investment while 'failing to reciprocate market access and maintain a level playing field' (European Commission 2016: 15). The document warned that China's increasing economic weight poses a 'risk for the global economy of negative spill-overs from distortions in China's economic system' (ibid). These dynamics have fundamentally changed the EU's perception of China: The Union no longer believes it can transform China into a likeminded liberal democratic regime. Instead, the EU has developed a sober view and a more realistic approach in order to compete with China in trade and investment.

The third important trend identified in this research is the fact that China has emerged as a major technology and cyber power with increasing capacity to shape the global governance of cyberspace and the digital economy. As the EU acknowledges, China has now become 'a leading technology power' (European Commission 2019a, b:1). The past 7 years have witnessed a tremendous growth in China's influence in the digital and high-technology spheres, which was built on China's increasingly coherent strategic vision for ICT (some examples of this include 'Made in China 2025', National Informatisation Strategy, Digital Silk Road within BRI). One direct consequence of China's rising digital power is the recent US-China technology war, marked by the USA's increasingly aggressive measures in terms of export controls. The US-China confrontation has had a far-reaching impact on the EU's perception of and actions towards China, especially in light of the fact that the USA has engaged in an aggressive campaign to persuade European partners to ban China's 5G technologies (Flides 2019).

\section{Securitising moves and multiple policy frames}

This sub-section shows that the abovementioned longer-term trends and specific precipitating events have both contributed to the EU's collective securitisation moves

\footnotetext{
${ }^{2}$ Whereas EU inbound investment into China had historically outpaced China's outbound investment, the trend has changed significantly since 2014 as a result of China's increasing Foreign Direct Investment in the EU. Notably, in 2016, new Chinese investment in Europe (35 billion Euros) was four times higher than the EU's FDI into China (8 billion Euros) (Zeneli 2019).
} 
towards China. As Sperling and Webber (2019) noted, these precipitating events have initiated the Union's securitising moves, which take the form of a series of speech acts presenting an existential threat to a referent object (e.g. to the EU itself) and to the systemic properties sustaining it (e.g. the EU's norms and rules governing its preferred international order). The language of these speech acts is replete with allusions to how the EU order has been subverted (by whom or what), how this affects the EU's own sense of security and what measures the EU should take in response (Sperling and Webber 2019).

It is interesting to observe that, while there has been clear evidence of the EU's collective securitisation moves towards China, the Union has not developed a coherent line of narrative when securitising China. By unpacking the speech acts adopted by key EU actors, this research finds that the EU has discursively constructed multiple referent objects, centring around different policy frames. In other words, from the EU's perspective, China constitutes an existential threat to a variety of 'social and political units that are threatened and have a legitimate claim to survival' (Sperling and Webber 2017:2) across multiple policy sectors. The following paragraphs discuss four different but interrelated policy frames underlying the EU's securitisation speech acts: (1) the Asian regional security frame, (2) the EU's (and global economic) security frame, (3) the political security frame and (4) the IT and cybersecurity frame.

\section{(1) Asian regional security frame}

Whereas the EU used to perceive China as a force for good that was committed to improving relations with its neighbours and promoting peace in Asia (European Commission 1998, 2006), recent EU documents have begun to describe China as a source of security concerns for Asian regional stability. For instance, the EU's 2016 communication stressed that 'regional security in the Asia-Pacific region will remain a challenge in the light of China's increasing assertiveness' (European Commission 2016:10). The EU's primary concerns are China's increasingly assertive behaviour and the deterioration of the situation in the South China Sea (ibid.). This securitising move is puzzling in the sense that China's regional policy in Asia seems not to pose any direct threat to EU security. Why has the EU drastically shifted its discourse and begun to think of China as a threat to Asian regional security that requires the EU's collective attention? What is the rationale behind this securitisation move? On the face of it, the referent object of the EU's speech act is concerned with regional stability and security in Asia; however, closer examination of EU discourse reveals the belief that China poses an existential threat to the EU's core economic and commercial interests. As noted in the EU's 2012 policy paper, 'East Asia security and stability is a precondition for the region's continued economic success' (EEAS 2012:5). As a result, China's assertive regional policy and the deterioration of South China Sea disputes may potentially threaten the EU's trade and investment interests (European Commission 2019a, b: 3-4) given that 'the large volume of international maritime trade passing through that area' is of prime importance to the EU (European Commission 2016:11). In a similar vein, the newly released 'EU Strategy for cooperation in the Indo-Pacific' points out that 
intense geopolitical competition adds to increasing tensions on trade and supply chains (Council of the EU 2021:2).

(2) European (and global economic) security frame

Unlike the EU's earlier view of China as a 'locomotive for regional and global growth' (European Commission 2003:6), key securitising actors such as the European Commission and European Parliament attempt to frame China as a threat to the EU's economic health and competitiveness, as well as to the global economy as a whole. The Commission's 2016 Joint Communication noted that China's adjustment towards a lower growth rate may generate 'short term volatility and risks' (European Commission 2016:6). The document further stressed that China's rising economic status 'increases the risk for the global economy of negative spill-overs from distortions in China's economic system and from possible sudden economic downturn' (ibid:5). Similar speech acts can be observed in the European Parliament's 2018 resolution on EU-China relations, which explicitly stated that China's state-led investment in Europe 'might hinder European strategic interests, public security objectives, competitiveness and employment' (European Parliament 2018:13). Moreover, the European Parliament added its voice to reinforce the view of China as a key economic threat. According to Reinhard Bütikofer, chairman of the delegation for relations with China, 'Chinese bluster, pressure and threats are becoming the norm - bullying as the new normal'. ${ }^{3} \mathrm{He}$ further noted that EU members have worked together more closely than before, 'jointly fighting Chinese price dumping and unfair subsidies, demanding reciprocity in public tenders, showing their concern for the security implications of sensitive investments', calling for the Union to overcome the problem of fragmented and divided implementations and to subsume national China policy to a 'European one'. ${ }^{4}$

In particular, economic risks of the EU's dependence on raw materials imports from China are frequently used when securitising China. On the one hand, the urgency of decarbonisation of the EU's economy has made guaranteeing a stable supply of critical raw materials a strategic agenda for the EU since raw materials are closely linked to clean technologies, such as the batteries used in electric cars. On the other hand, Europe is heavily dependent on raw materials imports from China, which accounts for $62 \%$ of the EU's supply of critical raw materials. The security of the supply chain of rare earth elements has raised additional concerns within the EU as the EU depends on China for as high as $98 \%$ of its rare earth imports. The EU therefore has increasingly stressed supply risks of critical raw materials caused by China's dominance in the raw materials market. As noted in 'Critical Raw Materials for Strategic Technologies and Sectors in the EU-A Foresight Study', China's near-monopolistic status renders the supply chains extremely vulnerable (European Commission 2020b). Similarly, in the

\footnotetext{
3 See the interview with Reinhard Bütikofer, conducted by Mercator Institute for China Studies, available at: https://merics.org/en/interview/reinhard-butikofer-we-are-learning-avoid-being-enchanted-winwin-rhetoric, accessed 5 January 2021.

4 Ibid.
} 
Communication 'Critical Raw Materials Resilience: Charting a Path towards Greater Security and Sustainability', the European Commission has raised concerns over the dominance of Chinese companies in rare earth metals' production (European Commission 2020c).

(3) Political security frame

Recent official EU discourse has labelled China an existential threat to the EU's core political values such as human rights, democracy and rule of law. EU concern over China's human rights and democratic conditions is not new; however, the past few years have witnessed the EU attempting to amplify its discourse that China's authoritarian regime and governance model pose an increasing threat. Notably, in the Commission's 2019a, b Joint Communication, the EU for the first time called China 'a systemic rival promoting alternative models of governance' (European Commission 2019a, b:1) as a result of 'Chinese external assertiveness and internal repression' (ibid:13). Although the EU did not see China's human rights issues as a key challenge to the international order before the 2010s, a closer evaluation of the EU's recent speech acts reveals that the EU has begun to recognise China's threat to the global human rights system (Roth 2020). The EU has issued numerous strong statements on Xinjiang at the Human Rights Council, including one that formed the basis for the largest joint governmental statement that China has faced (Roth 2020; European Parliament 2019a). Additionally, in November 2020, the EU described Beijing's adoption of national security law as a 'severe blow' to Hong Kong's autonomy and called for the resolution to be immediately reversed (Council of the EU 2020). Similar securitising moves can be observed in the official discourse adopted by key EU institutions such as the European Parliament. For instance, the European Parliament sees China's planned national security legislation in Hong Kong as a 'breach' of China's commitments and obligations under international law which 'threatens to severely damage the relationship of trust between China and the EU' (European Parliament 2020).

More recently, the COVID-19 pandemic has become a turf in the battle of narratives between the EU and China. China has been accused of influencing the German government to speak positively regarding its response to the pandemic (Reuters 2020). An internal note from Koen Doens, the director-general of the Commission's development arm, DEVCO, stated that 'COVID-19 risks being politicised to the advantage of international actors with a different agenda to ours. This is the case of China' (Chadwick 2020). Similarly, The European Union's top diplomat Josep Borrell warned China against 'politics of generosity' aimed at influencing individual EU countries by offering medical equipment to fight the COVID-19 pandemic (Borrell 2020). He pointed out that China was proactively promoting the message that it is a 'responsible and reliable partner' (ibid.). He therefore called on the EU to stand ready for a 'struggle for influence' in a 'global battle of narratives' (ibid.).

(4) Information technology (IT) and cybersecurity frame

Another securitising move by the EU centres around technology and cyber security. Essentially triggered by China's progress in developing new technologies, this securitising move has often been intertwined with other policy frames 
such as economic security, human rights and democracy, and can involve various referent objects that the EU believes have been threatened.

For example, the EU has recently labelled China as a security concern because of disinformation and online manipulation. In January 2020, Věra Jourová, the Vice President of the European Commission, made a speech entitled 'Disinfo Horizon: Responding to Future Threats', which explicitly described China as an increasing threat. In the speech, Jourová noted:

Disinformation and foreign interference are a soft underbelly of our democracy, because they attack one of our dearest values - freedom of speech and the right to information. There are specific external actors - namely Russia, and increasingly China - that are actively using disinformation and related interference tactics to undermine European democracy, and will continue doing so until we demonstrate that we will not tolerate this aggression and interference (European Commission 2020a).

This speech is a telling example of the EU's adoption of unambiguous language labelling China as a clear threat to the EU's democracy, freedom of speech and right to information. Another concrete example of the EU's securitising move can be found in its recent attempts to frame China as an 'IT threat' (European Parliament $2019 \mathrm{~b}$ ) or accusing it of 'theft of trade secrets through cyber' (European Commission 2018a, b:1). In a press release issued by the European Parliament in 2019, China was explicitly referred to as an 'IT threat' to the EU. More specifically, the document considered 'Chinese state security laws a threat to EU cybersecurity' and subsequently called on the European Commission and member states to tackle cybersecurity threats and vulnerabilities deriving from China and to establish a strategy to reduce the EU's dependence on foreign cybersecurity technology (European Parliament 2019c).

In addition, the EU's discourse concerning China's IT and cybersecurity threats has been entangled with other referent objects such as EU trade, investment and military security. For instance, in the 2019 Joint Communication 'EU-China: a strategic outlook', the EU perceived China's foreign investment in strategic sectors and acquisitions of critical assets, especially $5 \mathrm{G}$ networks, as a source of concern that 'can pose risks to the EU's security' (European Commission 2019a, b:9).

\section{Audience response: divided views among EU member states}

From the perspective of collective securitisation theory, audience may take various forms, ranging from international public opinion, other international institutions, to policy elites and domestic publics. Nevertheless, collective securitisation emphasised that the most important audience should be state representatives - namely 'the very components which constitute the international organization in the first place' (Sperling and Webber 2019:242). While acknowledging the existence of diverse groups of audience, this study focuses on the official discourses and responses from EU member states that have closely engaged in the EU's securitising moves. 
This research finds that, whereas some securitising moves have increasingly taken hold among the Union's internal audience, there exists a high degree of divergence in terms of the audience response across different policy frames. In other words, EU member states adopt considerably divergent stances on whether China constitutes an existential threat. As will be explained in the later section, the contentions between the securitising actors (EU institutions) and audience (EU member states) may hinder the EU's translation of securitising moves into actual policy outputs.

Specifically, the EU's audience holds divergent views with regard to the first policy frame (Asian regional security frame). Notably, while France, Germany and Britain wanted to adopt an assertive approach urging China to uphold international law, other EU member states including Hungary and Greece were unwilling to criticise Beijing. A high degree of divergence is also evidenced in EU member states' different stances on human rights issues in their dealings with Beijing. Whereas some EU member states such as Germany and Sweden have deployed a proactive and vocal approach criticising human rights, democracy and rule of law in China, some other European countries including France, the Netherland and Belgium are more cautious about generating public pressure on China when defending these core norms. In addition, countries such as Portugal, Poland and Romania do not openly engage in the discussion on political values in public. On some occasions, some EU member states tend to be counteractive. For instance, Hungary derailed Brussels' consensus by refusing to sign a joint statement concerning the reported torture of detained lawyers in China in 2017. Similarly, in the same year, Greece blocked an EU statement criticising Beijing's human rights record, which marked the first time Brussels failed to issue a joint statement at the UN Human Rights Council (Jerdén and Rühlig 2019).

The EU audience's conflicted views can also be observed in the economic security frame and IT and cybersecurity frame. Specifically, different member states of the Union hold a divergent view about whether China should be perceived as an existential threat in the economic realm. A telling example is that Europe remains severely divided into its responses and perceptions vis-à-vis China's Belt and Road Initiative. For instance, in 2018, while 27 EU member states' ambassadors endorsed a statement that sharply criticised BRI, condemning it as threatening free trade, Hungary was the only country that refused to sign the document (European Parliament 2018; Prasad 2018). With Italy becoming the first G7 country to join the BRI in March 2019, German Foreign Minister Heiko Maas has criticised Italy's decision to become part of the BRI, warning that countries hoping to do 'clever business with the Chinese will wonder when they suddenly wake up in dependency'. 5

With regard to the IT, technology and cybersecurity frame, the picture is mixed. For instance, whereas a group of members in the European Parliament explicitly identified Chinese 5G vendors Huawei and ZTE as 'high-risk' companies that pose

\footnotetext{
5 Heiko Maas made this comment in an interview with Germany's Welt Am Sonntag newspaper, cited in DW News, available at: https://www.dw.com/en/chinese-investments-in-europe-german-eu-commission er-floats-eu-veto-right/a-48045932, accessed 5 January 2021.
} 
an existential threat to network security in Europe, ${ }^{6}$ governments of EU member states remain divided on this issue. While the Spanish government attempts to avoid imposing an explicit ban against Huawei in its new 5G Cybersecurity Act, Germany's position has shifted drastically over the past 2 years. In late 2018, the German government mentioned that there is no legal basis for excluding any particular company from the $5 \mathrm{G}$ networks in Germany nor were any such actions planned. Nevertheless, in January 2019, the German government undertook a reassessment against Huawei, with the country's intelligence and security agencies explicitly advising the government to exclude Huawei from the construction of 5G networks (Düben 2019). Interestingly, a number of central and eastern European countries that have been part of the 17+1 framework-including Romania, Poland, the Czech Republic, Estonia and Latvia-aligned with Washington on the $5 \mathrm{G}$ issue, deciding to ban Huawei from future $5 \mathrm{G}$ networks (The Guardian 2020).

Despite the divergent approaches, it can be observed that the securitising move concerning IT threat and cybersecurity has gradually gained ground among an increasing number of EU member states. In 2019, the Constitution Protection Bureau of Latvia published an annual report, explicitly stating that China poses 'a serious threat to the security and interests of Western countries' given an increasing number of China's cyber operations (Constitution Protection Bureau of Latvia 2019). Furthermore, in November 2020, the Security Information Service of the Czech Republic published a report, stressing that Russian and Chinese cyberespionage activities constitute a serious risk to the country's ICT infrastructure and cybersecurity (BIS 2019).

\section{Policy output and new status quo}

Successful securitisation requires a shift in the policy actions of the relevant actor. Such actions are not necessarily of an emergence nature. A logic of securitisation is present when 'the action taken is justified by the securitising actor with reference to the threat [that is] identified and declared in the securitising move' (Floyd 2016: 679). The collective securitisation of China has important implications for the EU's overall policy towards China as well as individual member states' policy towards China. As discussed earlier, the EU has attempted to securitise China revolving around multiple frames, including the Asian regional security frame, economic security frame, political security frame and cybersecurity frame. Accordingly, the EU's policy outputs coming out of its securitising moves in terms of China are mostly justified with reference to the aforementioned security frames. Nevertheless, it is interesting to observe that although the political security frame is frequently referenced in the EU's securitising moves of China, the EU does not design specific policy instrument in response to this security challenge.

\footnotetext{
${ }^{6}$ See 'Letter to EU telecom and trade ministers and to European Commissioners Thierry Breton, Margrethe Vestager and Valdis Dombrovskis', available at: https://www.politico.eu/wp-content/uploads/ 2020/10/Clean-MEPs-letter-on-5G-and-trade-141020-1.pdf, accessed 5 January 2021.
} 
This research also finds that the process of translating securitising moves into actual policy outputs is significantly affected by the degree of divergence in terms of audience response across different policy frames. In other words, since EU member states hold divergent stances on whether China constitutes a threat, member states react differently to the EU's policy instruments dealing with China. The EU's policy output in response to threats posed by China mostly falls within the following categories. The first category of policy instruments can be summarised as the EU's efforts to address its concerns over possible Asian regional instability caused by China. One example of this category is the EU's reaction to the South China Sea disputes. In March 2016, the EU issued its first official statement on the South China Sea, expressing its support for 'maintaining a legal order for the seas and oceans based upon the principles of international law'. While not explicitly mentioning China, the statement pointed out that the EU was 'concerned about the deployment of missiles on islands in the South China Sea' (Council of the EU 2016a).

In July 2016, following the Hague Tribunal's ruling with regard to the South China Sea dispute, the EU issued a further statement noting 'the need for the parties to the dispute to resolve it through peaceful means, to clarify their claims and pursue the in respect and in accordance with international law, including the work in the framework of UNCLOS' (Council of the EU 2016b). Nevertheless, the July 2016 statement was widely viewed as weak. Instead of calling for China to respect the tribunal's ruling, it only acknowledged that decision. In comparison, the USA and Japan explicitly urged China to respect the court's decision. The EU's statement mostly reflected significant divergence among EU member states regarding how to react to the South China Sea disputes. Whereas Greece, Hungary and Croatia were unwilling to criticise Beijing due to their dependence on Chinese investment, France, Germany and the UK explicitly stated that Beijing must uphold international law (Emmott 2016).

The EU's declarations concerning the South China Sea dispute and EU member states' naval operations in and around the South China Sea both represent concrete examples of the EU's efforts to act as a more significant security actor in Asia and to counter China's significant military presence in the region. At the same time, however, EU member states continue selling military equipment to China. Despite the fact that the arms embargo on China is still in place, France, Germany, the UK and Italy are the main suppliers of dual-use technologies to China, which exerts a significant influence on China's military build-up (Pejsova 2018). In other words, the individual EU member states' actions in terms of arm exports have significantly constrained the EU's capacity to develop a coherent policy output to counter the potential security challenges posed by China in Asia-Pacific region.

The second category of EU's policy response to its security concerns over China mostly focuses on the economic sphere. For instance, the EU has taken major steps forward in protecting its interest from China's investment. The EU has claimed that China's investments 'frequently neglect socioeconomic and financial sustainability' (European Commission 2019a, b, 4). Because of this, the EU has established a framework for screening foreign direct investment, which entered into force in April 2019 and fully applied from November 2020 (European Council 2019). 
Another example is how the EU reacts to China's BRI. Because of its concerns about China's approach to connectivity within the framework of the BRI, the EU has sought to develop its own approach towards connectivity. The EU's efforts in this regard are evidenced by the more frequent use of the term connectivity in its policy papers. Whereas the EU's 2012 guidelines on foreign and security policy in East Asia did not mention the term 'connectivity' at all, the 2016 European Union global strategy stressed the need to develop 'a coherent approach to China's connectivity drives westwards' through policy tools such as Asia-Europe Meeting (ASEM), the EU-China connectivity platform and the EU-ASEAN framework (EEAS 2016: 37-8). As an important step towards the formulation of a coherent EU approach to connectivity, in September 2018, the European Commission produced the Joint Communication 'Connecting Europe and Asia' (European Commission 2018a, b). The EU described this communication as a European way of connecting Asia and Europe, but observers pointed out that this connectivity plan was initiated by the EU to counterbalance the BRI (Chen 2018).

One project in this field merits specific attention: the EU-Japan Partnership on Sustainable Connectivity and Quality Infrastructure adopted in 2019. This covers all dimensions of connectivity including digital, transport, energy and people-to-people exchanges. While this project does not mention China by name, it is clearly designed with China's BRI in mind. Previously, the EU had announced that it would allocate $€ 60$ billion to fund infrastructure connecting Europe and Asia. Nevertheless, in contrast with the hundreds of billions that China plans to invest in the BRI, the EU's budget seems relatively modest. The EU-Japan connectivity partnership will allow the EU and Japan to fund certain infrastructure projects with the participation of private financial institutions. Doing so, the EU, cooperating with Japan, responds to its concerns over financial instruments under the framework of BRI.

Despite the EU's efforts to develop a cohesive approach towards the BRI, member states have adopted diverse policies in reaction to it. For instance, Greece officially signed up for the BRI scheme in 2018. The deputy prime minister of Greece, Yannis Dragasakis, reaffirmed Greece's support for the BRI and stated that the EU's concern about China was in danger of becoming a 'self-fulfilling prophecy'. ${ }^{7}$ In March 2019, the Italian government signed a BRI-related memorandum of understanding (the 'China-Italy MoU'), which made Italy the first member of the Group of Seven major developed economies to conclude a BRI cooperation instrument. These examples demonstrate that whereas the EU has sought to address concerns over China's BRI at the EU level, member states have responded to the BRI according to their own securitising preferences.

The EU's policy response to its economic security concerns over China is also evidenced in the EU's report on state-induced market distortions in China. This 465page report, which was published in December 2017, proposed a new methodology for calculating dumping margins (European Commission 2017a, b). This report

\footnotetext{
7 Greece says EU's China concerns must not harm its economic interests, available on <https://www. scmp.com/news/china/diplomacy/article/3004724/greece-says-eus-china-concerns-must-not-harm-itseconomic $>$, accessed 21 December 2020.
} 
indicated a significant shift in the EU's approach to dealing with anti-dumping issues. One Chinese diplomat noted that whereas the EU had long been unsatisfied with China's human rights conditions and certain economic policies, the Commission's report indicated that the focus of its critique had shifted to China's overall development model (Interview with a Chinese diplomat, Brussels, Dec 2018).

The third category of the EU's policy response to security concerns over China mostly falls within the EU's efforts to counterbalance China's increasing influence in the field of cybersecurity. On 8 March 2019, the Commission and the High Representative proposed the establishment of a horizontal sanction regime to counter cyberattacks, which would enable the EU to respond to cyberattacks with a 'significant effect' (European Commission 2019a, b). In July 2020, the Council applied restrictive measures to six individuals accused of cyberattacks against European targets-two Chinese citizens and four Russians - as well as three organisations, one each from China, North Korea and Russia (European Council 2020). Although this regime is not explicitly designed to counter China's cyberattacks, the significant number of Chinese citizens and organisations involved in the EU's first-ever cybersanction implies that this sanction regime is targeting China.

Furthermore, in January 2020, the EU proposed a set of tools aiming to limit the EU's dependence on Chinese telecom giant Huawei. According to Thierry Breton, the EU's internal market commissioner and cybersecurity chief, member states decided, 'for the first time in our history, that it would be appropriate to have a coordinated approach on protecting our infrastructure'. ${ }^{8}$ Although the EU does not refer to Huawei or China by name, observers point out that those tools are targeted at China and its vendors, such as Huawei and ZTE.

These important EU policy developments in response to cybersecurity concerns over China were followed by changes at the domestic level. As discussed earlier, a consensus that China has posed a threat to cybersecurity is gradually achieved among EU member states. Therefore, an increasing number of EU member states have made substantial moves in the field of cybersecurity with reference to China. The UK, for instance, has taken a tough approach to the Chinese telecom giant, Huawei. In January 2020, the British government ruled that highrisk vendors such as Huawei should be excluded from the network core and could not make up more than $35 \%$ of the tech used in the network periphery. However, 6 months later, the British government reversed this decision. Under the new ruling, Huawei equipment should be removed from British $5 \mathrm{G}$ networks by end of 2027. France has followed the UK and required local telecom operators to stop using Huawei by 2028. Although many EU member states have so far adopted a softer approach to Chinese telecom companies, observers pointed out that the UK and France's ban of Huawei could bring a shift to harder lines (Cerulus 2020). For instance, Germany is shifting its cybersecurity policy towards China. Initially, the German government decided not to rule out Huawei. On August 11, 2020, Germany's Federal Network Agency (BNetzA) and the Federal Office for

\footnotetext{
8 See 'Europe's Huawei plan explained', available at https://www.politico.eu/article/europe-eu-huawei5g-china-cybersecurity-toolbox-explained/, accessed 04 January 2021.
} 
Information Security (BSI) published the final draft of security standards for the construction of $5 \mathrm{G}$ networks by Germany's telecom operators. There is not a single clause mentioning Huawei in this over 80-page-long document. Nevertheless, in December 2020, the German cabinet has agreed on a new IT law. Although this law does not exclude the Chinese companies outright from the German telecoms market, it introduces much more stringent checks of telecom suppliers, giving the authorities the power to ban Chinese telecom companies from Germany's 5G network on security grounds (Chazan 2020).

The discussion above indicates that the EU has designed a number of policies dealing with its concerns over China with regard to multiple frames. Nevertheless, due to member states' divergent opinions regarding whether China constitutes a threat, the implementation of EU measures at the domestic level is significantly constrained. Therefore, no new status can be observed. The only exception is the EU's policy instruments dealing with cybersecurity threats posed by China. Since member states have gradually accepted the EU's securitising move over China with regard to cybersecurity frame, EU policies towards China in the field of cybersecurity are followed by changes at the member state level.

\section{Conclusion}

In an attempt to provide a reflection on the recent dynamics concerning the EU's changing foreign policy strategy vis-à-vis China, this article draws on the theoretical framework of collective securitisation to develop an analysis of the deterioration of the EU-China relations over the past decade. This article maintains that, whereas the EU did not perceive China as a threat in the first four decades of EU-China relations, the Union's foreign policy discourses and behaviours towards China have undergone a drastic shift since the 2010s, demonstrating strong signs of collective securitisation attempts. Specifically, the Union has started to frame China as an existential threat through the development of a series of speech acts directed at multiple policy frames concerning Asian regional security, economic security, political security and IT/cyber security. The research further argues that it is a combination of long-term trends and specific sets of precipitating events that has contributed to galvanising the Union's collective securitising discourses and subsequent policy initiatives vis-à-vis China. Nevertheless, the EU's securitising narratives have not resulted in a coherent audience response among the EU member states. The Union's role as a collective securitising actor and its capability to translate its securitising moves into policy outputs and new status quo have been hampered by the audience's divided stance on China. All in all, despite salient evidence of securitising moves across various policy frames, the Union's collective securitisation of China has yet to be considered successful. This is because the EU as a collective securitising actor has not acquired sufficient audience acceptance, which in turn hampered the Union's ability to implement common policies and to consolidate the new status quo discourse. 


\section{Declarations}

Ethics approval and consent to participate Not applicable.

Consent for publication Not applicable.

Adherence to national and international regulations Not applicable.

Conflict of interest The authors declare no competing interests.

\section{References}

Assembly of Western European Union (WEU) (1978) Draft recommendation on China and European security. Available at: http://aei.pitt.edu/74214/. Accessed 5 Jan 2021.

Baker L, Chalmers J (2020) As Britain bans Huawei, US pressure mounts on Europe to follow suit. Reuters. Available at: https://uk.reuters.com/article/uk-britain-huawei-europe/as-britain-bans-huaweiu-s-pressure-mounts-on-europe-to-follow-suit-idUKKCN24F1X4. Accessed 5 Jan 2021.

Balzacq T (ed) (2010) Understanding securitisation theory: how security problems emerge and dissolve. Routledge, London

Banks M (2020) Deterioration in EU relations with China. Available at: https://www.eupoliticalreport.eu/ deterioration-in-eu-relations-with-china/. Accessed 5 Jan 2021

Brown K, Beatson S (2016) The European Union and China: the need for a more politicised relationship. Asia Pac Policy Stud 3(3):412-419

Borrell J (2020) The coronavirus pandemic and the new world it is creating. EEAS homepage. Available at https://eeas.europa.eu/headquarters/headquarters-homepage/76379/corona-virus-pandemic-andnew-world-it-creating_en. Accessed on 21 July 2021

Buzan B, Wæver O (2003) Regions and powers: the structure of international security (No. 91). Cambridge University Press, Cambridge

Buzan B, Wæver O (2009) Macrosecuritisation and security constellations: reconsidering scale in securitisation theory. Rev Int Stud 35:253-276

Buzan B, Wæver O, de Wilde J (1998) Security: a new framework of analysis. Lynne Rienner Publishers, London

Caballero-Anthony M (2008) Non-traditional security and infectious diseases in ASEAN: going beyond the rhetoric of securitization to deeper institutionalization. Pacific Review 21(4):507-525

Cerulus L (2020) Europe's Huawei plan explained. Politico. Available at: https://www.politico.eu/article/ europe-eu-huawei-5g-china-cybersecurity-toolbox-explained/. Accessed 4 Jan 2021

Chadwick V (2020) 'The politics of generosity': Brussels aims to counter Chinese narrative on coronavirus. DEVEX. Available at https://www.devex.com/news/the-politics-of-generosity-brussels-aims-tocounter-chinese-narrative-on-coronavirus-96944. Accessed on 21 July 2021

Chazan G (2020) Germany sets high hurdle for Huawei, Financial Times. Available at: https://www.ft. com/content/cadc6d26-97e1-4e63-b6ca-f24110c90379. Accessed 5 Jan 2021

Chen X (2018) The role of ASEAN's identities in reshaping the ASEAN-EU relationship. Contemp Southeast Asia 40(2):222-246

Christiansen T (2016) A liberal institutionalist perspective on China-EU relations. In: China, the European Union, and the International Politics of Global Governance. Palgrave Macmillan, New York, pp 29-50

Christiansen T, Kirchner E, Wissenbach U (2018) EU-China relations. Red Global Press, London

Constitution Protection Bureau of Latvia (2019) 2019 Annual Report. Available at: https://www.sab.gov. 1v/files/Public_report_2019.pdf. Accessed 5 Jan 2021

Cottey A (2017) The EU-China partnership: institutionalisation and the limits of liberal logic. In: Deepening the Eu-Chinapartnership in an unstable world. Routledge, pp 45-54

Council of the EU (2016a) Declaration by the high representative on behalf of the EU on recent developments in the South China Sea. Available at: https://www.consilium.europa.eu/en/press/press-relea 
ses/2016/03/11/hr-declaration-on-bealf-of-eu-recent-developments-south-china-sea/. Accessed 5 Jan 2021

Council of the EU (2016b) Declaration by the high representative on behalf of the EU on the award rendered in the arbitration between the Republic of the Philippines and the People's Republic of China. Available at: https://www.consilium.europa.eu/en/press/press-releases/2016/07/15/southchina-sea-arbitration/. Accessed 5 Jan 2021

Council of the EU (2020) Hong Kong: declaration by the high representative on behalf of the EU on the disqualification of members of the Hong Kong Legislative Council. Available at: https:// www.consilium.europa.eu/en/press/press-releases/2020/11/12/hong-kong-declaration-by-thehigh-representative-on-behalf-of-the-eu-on-the-disqualification-of-members-of-the-hong-konglegislative-council/. Accessed 5 Jan 2021

Council of the EU (2021) EU strategy for cooperation in the Indo-Pacific-council conclusion. Available at: https://data.consilium.europa.eu/doc/document/ST-7914-2021-INIT/en/pdf. Accessed 26 July 2021

Cross MKD (2017) Counter-terrorism in the EU's external relations. J Eur Integr 39(5):609-624

Dorussen H, Christiansen T (2018) Security cooperation in EU-China relations: towards convergence? Eur Foreign Aff Rev 23(3):287-304

Düben B (2019) Are the gloves coming off in China-Germany economic relations? The Diplomat. Available at: https://thediplomat.com/2019/05/are-the-gloves-coming-off-in-china-germany-economicrelations/. Accessed 5 Jan 2021

EEAS (2012) Guidelines on the EU's foreign and security policy in East Asia. Available at: http:// www.eeas.europa.eu/archives/docs/asia/docs/guidelines_eu_foreign_sec_pol_east_asia_en.pdf, Accessed 5 Jan 2021

EEAS (2016) Shared vision, common action: a stronger Europe. A global strategy for the European Union's foreign and security policy. Available at: https://eeas.europa.eu/archives/docs/top_stori es/pdf/eugs_review_web.pdf. Accessed 04 Jan 2021

Emmott R (2016) EU's statement on South China Sea reflects divisions. Reuters. July 15, 2016. Available at: https://www.reuters.com/article/uk-southchinasea-ruling-eu-idUKKCN0ZV1UP

Enemark C (2017) Ebola, disease-control, and the security council: from securitization to securing circulation. J Glob Secur Stud 2(2):137-149

European Commission (1995) A long term policy for China-Europe relations. Available at: http:// www.eeas.europa.eu/archives/docs/china/docs/com95_279_en.pdf, Accessed 5 Jan 2021

European Commission (1998) Building a comprehensive partnership with China. Available at: https:// eur-lex.europa.eu/LexUriServ/LexUriServ.do?uri=COM:1998:0181:FIN:EN:PDF, Accessed 5 Jan 2021

European Commission (2001) EU strategy towards China: implementation of the 1998 communication and future steps for a more effective EU policy. Available at: https://eur-lex.europa.eu/legalcontent/EN/TXT/?uri=CELEX:52001DC0265, Accessed 5 Jan 2021

European Commission (2003) A maturing partnership - shared interests and challenges in EU-China relations. Available at: https://eur-lex.europa.eu/legal-content/EN/TXT/?uri=celex:52003DC0533, Accessed 5 Jan 2021

European Commission (2006) EU - China: closer partners, growing responsibilities. Available at: https://eur-lex.europa.eu/legal-content/EN/ALL/?uri=celex\%3A52006DC0631, Accessed 5 Jan 2021

European Commission (2016) Elements for a new EU strategy on China. Available at: https://eeas. europa.eu/archives/docs/china/docs/joint_communication_to_the_european_parliament_and_ the_council_-_elements_for_a_new_eu_strategy_on_china.pdf, Accessed 5 Jan 2021

European Commission (2017a) European Commission staff working document: on significant distortions in the economy of the People's Republic of China for the purposes of trade defence investigations. Available at: https://trade.ec.europa.eu/doclib/docs/2017/december/tradoc_156474.pdf, Accessed 5 Jan 2021

European Commission (2017b) On significant distortions in the economy of the People's Republic of China for the purposes of trade defence investigations. Available at: https://trade.ec.europa.eu/ doclib/docs/2017/december/tradoc_156474.pdf, Accessed 5 Jan 2021

European Commission (2018a) Connecting European and Asia-building blocks for an EU strategy. Available at: https://eeas.europa.eu/sites/eeas/files/joint_communication_-_connecting_europe_ and_asia_-_building_blocks_for_an_eu_strategy_2018-09-19.pdf, Accessed 04 Jan 2021 
European Commission (2018b) The scale and impact of industrial espionage and theft of trade secrets through cyber. Available at: https://op.europa.eu/en/publication-detail/-/publication/4eae21b2-454711e9-a8ed-01aa75ed71a1/language-en, Accessed 5 Jan 2021

European Commission (2019a) EU-China: a strategic outlook. Available at: https://ec.europa.eu/ commission/sites/beta-political/files/communication-eu-china-a-strategic-outlook.pdf, Accessed 5 Jan 2020

European Commission (2019b) European Commission and HR/VP contribution to the European Council: EU-China - a strategic outlook. Available at: https://ec.europa.eu/commission/sites/beta-political/ files/communication-eu-china-a-strategic-outlook.pdf, Accessed 5 Jan 2021

European Commission (2020a) Disinfo Horizon: responding to future threats. Available at: https://ec. europa.eu/commission/presscorner/detail/et/SPEECH_20_160, Accessed 5 Jan 2021

European Commission (2020b) Critical raw materials for strategic technologies and sectors_a foresight study. Available at: https://ec.europa.eu/docsroom/documents/42881, Accessed 26 July 2021

European Commission (2020c) Communication from the Commission to the European Parliament, the Council, the European Economic and Social Committee and the Committee of the Regions: critical raw materials resilience: charting a path towards greater security and sustainability. Available at: https://eur-lex.europa.eu/legal-content/EN/TXT/PDF/?uri=CELEX:52020DC0474\& from=EN, Accessed 26 July 2021

European Parliament (2018) European Parliament resolution of 12 September 2018 on the state of EUChina relations. Available at: https://www.europarl.europa.eu/doceo/document/TA-8-2018-0343_ EN.html, Accessed 5 Jan 2021

European Parliament (2019a) Joint motion for a resolution on the situation of the Uyghurs in China. Available at: https://www.europarl.europa.eu/doceo/document/RC-9-2019-0246_EN.html, Accessed 5 Jan 2021

European Parliament (2019b) European Parliament resolution of 12 March 2019 on security threats connected with the rising Chinese technological presence in the EU and possible action on the EU level to reduce them. Available at: https://www.europarl.europa.eu/doceo/document/TA-8-2019-0156_ EN.html, Accessed 5 Jan 2021

European Parliament (2019c) MEPs adopt Cybersecurity Act and want EU to counter IT threat from China. Available at: https://www.europarl.europa.eu/news/en/press-room/20190307IPR30694/mepsadopt-cybersecurity-act-and-want-eu-to-counter-it-threat-from-china, Accessed 5 Jan 2021

European Parliament (2020) Joint motion for a resolution on the PRC national security law for Hong Kong and the need for the EU to defend Hong Kong's high degree of autonomy. Available at: https://www.europarl.europa.eu/doceo/document/RC-9-2020-0169_EN.html, Accessed 5 Jan 2021

European Parliament and the Council of the European Union (2019) Regulation (EU) 2019/452 of the European Parliament and of the Council of 19 March 2019: establishing a framework for the screening of foreign direct investment into the Union. Available at: https://eur-lex.europa.eu/eli/reg/2019/ 452/oj, Accessed 5 Jan 2021

Flides N (2019) US urges Europe to exclude Huawei from 5G network builds. Financial Times. Available at: https://www.ft.com/content/a4834900-39ce-11e9-b856-5404d3811663, Accessed 5 Jan 2021

Floyd R (2010) Security and the environment: securitisation theory and US environmental security policy. Cambridge University Press

Floyd R (2016) Extraordinary or ordinary emergency measures: what, and who, defines the 'success' of securitization? Camb Rev Int Aff 29(2):677-694

Floyd R (2019) Collective securitisation in the EU: normative dimensions. West Eur Polit 42(2):391-412

Fox J, Godement F (2009) A power audit of EU-China relations. European Council on Foreign Relations, London, pp 20-27

Geeraerts G (2019) The EU-China partnership: balancing between divergence and convergence. Asia Eur J 17(3):281-294

Haacke J, Williams PD (2008) Regional arrangements, securitization, and transnational security challenges: the African Union and the Association of Southeast Asian Nations compared. Secur Stud 17(4):775-809

Hanrieder T, Kreuder-Sonnen C (2014) WHO decides the exception? Securitization and the Emergency Governance in Global Healthy. Secur Dialogue 45(4):331-348

Hofmann SC, Staeger U (2019) Frame contestation and collective securitisation: the case of EU energy policy. West Eur Polit 42(2):323-345

Huysmans J (2006) The politics of insecurity: fear, migration and asylum in the European Union. Routledge, Abingdon 
Hyttinen T, Heinikoski S (2019) Justification of supranational criminal law-analysis of collective securitization in the EU-level harmonization of money laundering provisions. Maastricht J Eur Comp Law 26(6):815-832

Interview with a Chinese diplomat, Brussels, December 2018.

Jerdén B, Rühlig T (2019) Divided approach to China and human rights. The Diplomat. Available at: https:// thediplomat.com/2019/03/europes-divided-approach-to-china-and-human-rights/, accessed 5 Jan 2021

Men J (2008) EU-China relations: from engagement to marriage? College of Europe EU Diplomacy Paper 7/2008, November 2008. EU Diplomacy Papers, 25.

Möller K (2002) Diplomatic relations and mutual strategic perceptions: China and the European Union. China Q 169:10-32

Pejsova E Introduction: Arms trade, dual-use technologies and the new dynamic in EU-Asia relations. In: Pejsova E (ed) Guns, Engines and Turbine: The EU's Hard Power in Asia, November 2018, 9

Prasad R (2018) EU ambassadors condemn China's Belt and Road Initiatives. The Diplomat. Available at: https://thediplomat.com/2018/04/eu-ambassadors-condemn-chinas-belt-and-road-initiative/, Accessed 5 Jan 2021

Rees N (2009) Eu-China relations: historical and contemporary perspectives. In: The European Union and China. Brill Rodopi, pp 29-46

Reuters Staff (2020) Germany says China sought to encourage positive COVID-19 comments. Reuters. Available at: https://www.reuters.com/article/us-health-coronavirus-germany-china-idUSKCN2280JW, Accessed 27 July 2021

Roth K (2020) Europe needs to stop China's assault on the global rights system. Available at:https://www.hrw. org/news/2020/02/11/europe-needs-stop-chinas-assault-global-rights-system, Accessed 5 Jan 2021

Schlag G (2016) Securitization theory and the evolution of NATO. In: Webber M, Hyde-Price A (eds) Theorising NATO: new perspectives on the Atlantic alliance. Routledge, Abingdon, pp 161-182

Scott D (2009) Environmental issues as a 'strategic' key in EU-China relations. Asia Eur J 7(2):211-224

Smith M (2014) EU-China relations and the limits of economic diplomacy. Asia Eur J 12(1-2):35-48

Sperling J, Webber M (2016) NATO and the Ukraine crisis: collective securitisation. Eur J Int Secur 2(1):19-46

Sperling J, Webber M (2017) NATO and the Ukraine crisis: collective securitisation. Eur J Int Secur 2(1):19

Sperling J, Webber M (2019) The European Union: security governance and collective securitisation. West Eur Polit 42(2):228-260

The Guardian (2020) Europe divided on Huawei as US pressure to drop company grows. Available at: https:// www.theguardian.com/technology/2020/jul/13/europe-divided-on-huawei-as-us-pressure-to-drop-compa ny-grows, Accessed 5 Jan 2021

The Security Information Service (BIS) of the Czech Republic (2019) Annual report of the security information service for 2019. Available at: https://www.bis.cz/public/site/bis.cz/content/vvz-2019-web-en-k-publikaci. pdf, Accessed 5 Jan 2021

Von der Burchard H (2019) EU slams China as 'systemic rival' as trade tension rises, Politico. Available at: https://www.politico.eu/article/eu-slams-china-as-systemic-rival-as-trade-tension-rises/, Accessed 5 Jan 2020

Wæver O (2000) The EU as a security actor: reflections from a pessimistic constructivist on post-sovereign security orders. In: Williams MC, Kelstrup M (eds) International relations theory and the politics of European integration: power, security, and community. Routledge, London

Webber D (2016) Declining power Europe: the evolution of the European Union's world power in the early 21 st century. Eur Rev Int Stud 3(1):31-52

Wright T (2020) Europe changes its mind on China. Brookings. Available at: https://www.brookings. edu/wp-content/uploads/2020/07/FP_20200708_china_europe_wright_v2.pdf. Accessed 5 Jan 2020

Zeneli V (2019) Mapping China's investments in Europe. The Diplomat. Available at: https://thediplomat.com/2019/03/mapping-chinas-investments-in-europe/, Accessed 5 Jan 2021

Zhang Y (2016) Introduction: Dynamism and contention: understanding Chinese foreign policy under Xi Jinping. Int Aff 92(4):769-772

Publisher's note Springer Nature remains neutral with regard to jurisdictional claims in published maps and institutional affiliations. 